International Journal of Software Engineering \& Computer Systems (IJSECS)

ISSN: 2289-8522, Volume 2, pp. 89-107, February 2016

CUniversiti Malaysia Pahang

DOI: http://dx.doi.org/10.15282/ijsecs.2.2016.8.0019

\title{
MODELING AND SIMULATION OF TRAFFIC FLOW: A CASE STUDY - FIRST RING ROAD IN DOWNTOWN MADINAH
}

\author{
Muhammad Nomani Kabir ${ }^{*}$, Yasser M. Alginahi², Ali I. Mohamed ${ }^{3}$ \\ ${ }^{1}$ Faculty of Computer Systems \& Software Engineering, University Malaysia Pahang, \\ 26300 Gambang, Pahang, Malaysia, \\ ${ }^{2}$ Deanship of Academic Services, Computer Science, Taibah University, P.O. Box 344, \\ Postal Code: 41411, Madinah, Saudi Arabia, \\ ${ }^{3}$ Leanco Consulting, Windsor, Ontario, Canada, \\ Email: nomanikabir@ump.edu.my*_\{alginahi, ali.idris2009\}@gmail.com
}

\begin{abstract}
Traffic assessment is extremely important for the performance evaluation of vehicleflow on a road network. This paper presents an assessment of traffic flow on the busiest road i.e., First Ring Road located at the central area of Madinah in Saudi Arabia. In this paper, the assessment of traffic-flow is performed by evaluating and analyzing the traffic on First Ring Road. This includes investigating the number of vehicles entering and exiting the central area through First Ring Road, the arrangements of the road, percentage of traffic entering versus exiting, etc. In addition, a new model for the traffic distribution along the roads intersecting with First Ring Road was built based on optimization. Our optimization model was formulated as a minimization problem of the difference between the measured number of vehicles and the sum of portions of vehicles from all entrances of First Ring Road that move out from each road. A simulation program was developed using Matlab to solve the optimization model. The simulation results show good agreement with the corresponding measurement data of vehicles at First Ring Road. Thus, our model can be used as a prediction model of vehicle movements.
\end{abstract}

Keywords: traffic congestion; Hajj; traffic network model; optimization

\section{INTRODUCTION}

The traffic in the central area of Madinah is the subject of this study. The central area of Madinah shown in Figure 1 encircled by First Ring Road, occupies around $2.16 \mathrm{~km}^{2}$. The area is accessed by 12 roads which connect First Ring Road. This area is very crowded especially during pilgrimage (Umrah and Hajj) seasons. According to the Saudi Central Department of Statistics and Information, the number of pilgrims during the seasons from 1995 to 2012 increased by approximately 70\%. Table 1 shows the number of pilgrims in the last 18 years (Saudi Central Department of Statistics and Information, 2013). Part of the Hajj trip of the pilgrims is to visit Madinah. Therefore, a large number of pilgrims visit Madinah from about a month before Hajj days until about a month after Hajj is over. In addition to this, people coming from abroad for Umrah also visit Madinah during the rest of the year. Thus, more traffic flows on the road network during Umrah and Hajj seasons. It is also noticed that the population of Madinah has increased significantly in the last decade to over one million and it is projected that the population could increase by $50 \%$ by 2025 due to economic growth of the city (Saudi Central Department of Statistics and Information, 2013). 


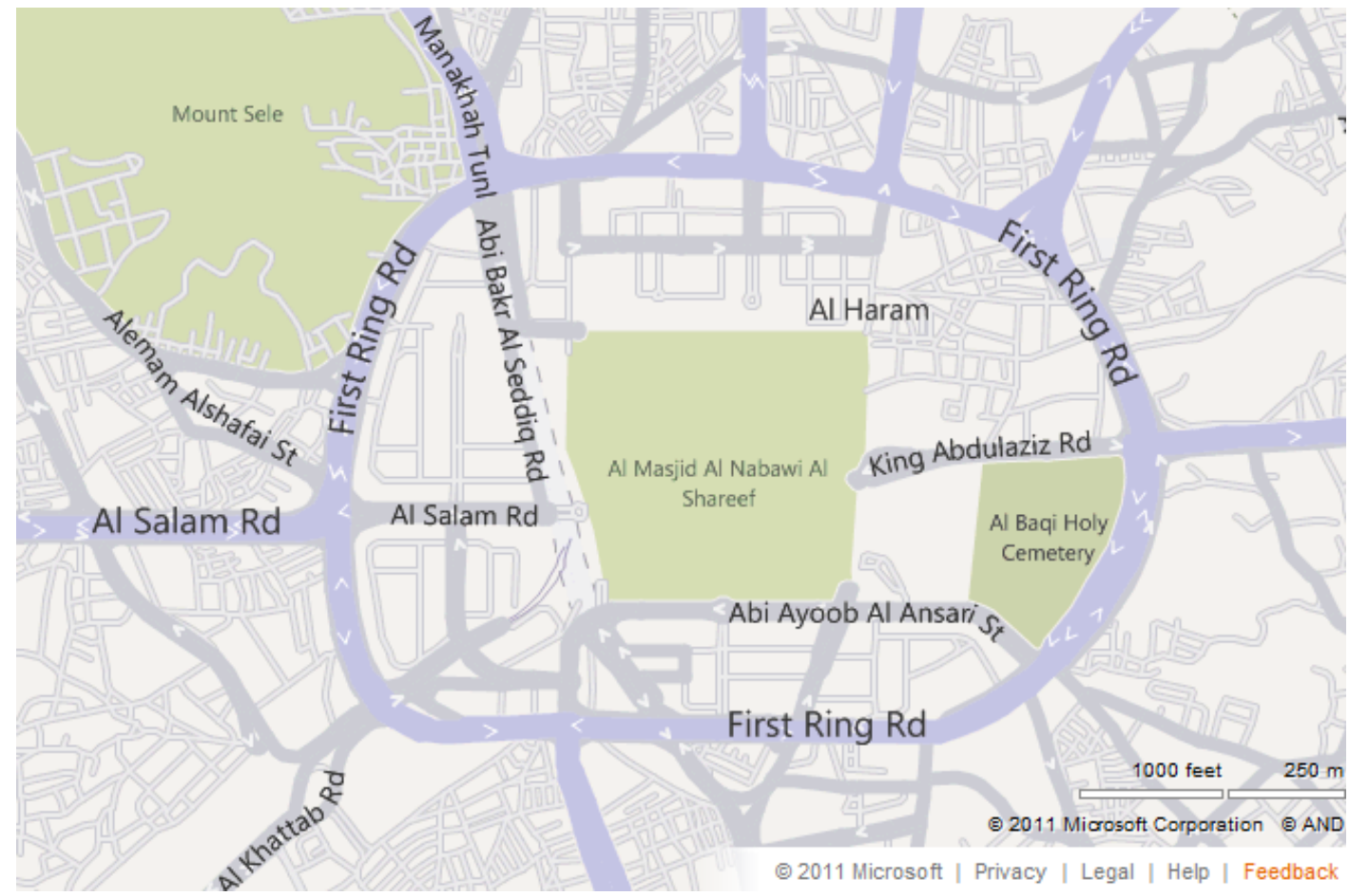

Figure 1. Central Area of Madinah (Enclosed by First Ring Road) (Bing Maps, 2013)

Table 1. The Number of Pilgrims for the Years from 1995 to 2012

\begin{tabular}{|c|c|c|c|}
\hline Year & $\begin{array}{c}\text { From Inside } \\
\text { Saudi } \\
\text { Arabia }\end{array}$ & $\begin{array}{c}\text { From Outside } \\
\text { Saudi Arabia }\end{array}$ & Total \\
\hline $\mathbf{1 9 9 5}$ & 784,769 & $1,080,465$ & $1,865,234$ \\
\hline $\mathbf{1 9 9 6}$ & 774,260 & $1,168,591$ & $1,942,851$ \\
\hline $\mathbf{1 9 9 7}$ & 699,770 & $1,132,344$ & $1,832,114$ \\
\hline $\mathbf{1 9 9 8}$ & 775,268 & $1,056,730$ & $1,831,998$ \\
\hline $\mathbf{1 9 9 9}$ & 571,599 & $1,267,555$ & $1,839,154$ \\
\hline $\mathbf{2 0 0 0}$ & 549,271 & $1,363,992$ & $1,913,263$ \\
\hline $\mathbf{2 0 0 1}$ & 590,576 & $1,354,184$ & $1,944,760$ \\
\hline $\mathbf{2 0 0 2}$ & 610,117 & $1,431,012$ & $2,041,129$ \\
\hline $\mathbf{2 0 0 3}$ & 592,368 & $1,419,706$ & $2,012,074$ \\
\hline $\mathbf{2 0 0 4}$ & 629,710 & $1,534,769$ & $2,164,479$ \\
\hline $\mathbf{2 0 0 5}$ & 700,603 & $1,557,447$ & $2,258,050$ \\
\hline $\mathbf{2 0 0 6}$ & 724,229 & $1,654,407$ & $2,378,636$ \\
\hline $\mathbf{2 0 0 7}$ & 746,511 & $1,707,814$ & $2,454,325$ \\
\hline $\mathbf{2 0 0 8}$ & 679,008 & $1,729,841$ & $2,408,849$ \\
\hline $\mathbf{2 0 0 9}$ & 699,313 & $1,613,965$ & $2,313,278$ \\
\hline $\mathbf{2 0 1 0}$ & 989,798 & $1,799,601$ & $2,789,399$ \\
\hline $\mathbf{2 0 1 1}$ & $1,099,522$ & $1,828,195$ & $2,927,717$ \\
\hline $\mathbf{2 0 1 2}$ & $1,408,641$ & $1,752,932$ & $3,161,573$ \\
\hline
\end{tabular}

The traffic in the central area of Madinah has become a major concern for authorities especially during prayer times where heavy crowds dominate between about an hour before and an hour after each prayer realizing that an immediate action has to be 
taken to ease this problem (Alginahi et al, 2013). Another concern in the city is the air quality and its effects on health. Given the fact that the peak temperatures in the summer exceed $45^{\circ} \mathrm{C}$, exhaust gas emission during that period increases causing serious degradation in quality of air. Therefore, the objectives of the work are: to perform the traffic assessment for the central area of Madinah in order to calculate the number of vehicles using First Ring Road at different times of the day; to identify if there are any differences in the level of traffic on certain routes connecting to Ring Road; to calculate the total number of vehicles intersecting with the ring road; and to provide recommendations on the traffic network in the area. The study was carried out between October, 2010 and June 2011 and the supervision of the survey teams was done by the authors of the study.

The literature presents many traffic road network models to address many issues related to traffic research such as noise pollution, air pollution, accidents, traffic prediction, signage, and surveillance. In addition, the concept of green traffic was also addressed in literature (Yu-Fan and Yan, 2011). However, in this work the concentration is on the work related to traffic assessment to model a ring road in the busy area of a city. Traffic assessments are usually carried out by municipalities for new proposed projects or developments, rezoning requests, traffic congestions, future regional planning and conducting traffic surveys in order to study the traffic behavior in accordance to specific future traffic projection. Usually traffic assessment studies the provided recommendation for some improvements to the area. Here, some examples of traffic assessment studies will be presented.

Traffic impact assessment determines the impact of a project or a development on the transportation and traffic systems. The work carried out by Rogidor and Teodoro in Metro Manila in Philippines compared the traffic impact assessment of two cases involving projects in different cities in Philippines the study examined the sustainability of the traffic management and transportation planning strategies. The outcome of the study recommended that the government must take an active role in promoting traffic impact assessment studies to ensure that all involved stakeholders participate in the process in order to carefully assess the impacts to proposed developments (Diliman, 2005).

The purpose of the traffic assessment study performed by Morrison Hershfield Limited for a proposed quarry located in the Dufferin County in Ontario, Canada was to evaluate the impact of traffic from the proposed project site on the level of service, capacity and operations on surrounding roads based on projected future traffic while the project completion is planned for 2021. The analysis was conducted on different scenarios based on the number of trucks entering and leaving the quarry area. The study recommended the following improvements depending on the different analyzed scenarios: adding staggered passing lanes, adding a left turn lane at the intersection and adding a new right turn lane at the intersection (Munir and Pham, 2012).

The study by Baby and Al-Sarawi (2011) aimed at determining the traffic impact for the new township redevelopment project in Kuwait city. This study was carried out at different times of the day for thirteen different roadway locations in order to study the impact of the project on the roadways. The study concluded that by 2013, the performance of the roadway network would deteriorate due to the projected growth in traffic. By the year 2016, the construction of the project will come to completion and the projected growth of traffic volumes is $30 \%$ over the present traffic (2007). Therefore, the impact of the future traffic on the roadway network will be significant, the amount of fuel consumption by vehicles will also increase significantly producing 
higher Carbon Monoxide (CO), Nitrogen Oxide (NO2) and Volatile Organic Compounds (VOC) emissions which will have a significant impact on air pollution and effect of air pollution on public health. URS Canada Inc. conducted a transportation assessment of potential traffic effects in the Durham and York regions in Ontario because of a proposed thermal treatment facility which would be developed in the municipality of Clarington. The assessment reported that the project was anticipated to account for $2 \%-3 \%$ of the total trips generated. It also concluded that traffic signals could be required, widening of some roads could also improve the traffic operations, and improvements to the ramp terminal intersections by the ultimate 2023 horizon year with the construction of Clarington Energy Business Park (CEBP).

The impact of traffic on air pollution has generated limited studies. Therefore, the review of traffic related air pollution exposure assessment studies is important. Han and Naeher (2006) provided a review of traffic related air pollution exposure assessment studies in the developing world. They also discussed the available standards for the pollutants: Particulate Matter (PM), CO, NO2, VOC and Polycyclic aromatic hydrocarbons (PAHs). The review also presented the advantages and disadvantages of various monitoring methods for these pollutants in exposure assessment studies. The paper concluded by presenting the limitations and gaps in the available studies and provided some recommendations for future research on traffic air pollutants in the developing world.

Some other work related to traffic modeling include the work of $\mathrm{Li}$ and $\mathrm{Lu}$ who presented a model for a new short-term freeway traffic flow predication based on combined Neural Network (NN) approach consisting of self-organizing feature map (SOM) and Elman NN, where the SOM was used to classify the traffic condition and the Elman NN identified the relationships between input and output in order to produce the prediction value. As a case study, performance of this model was estimated using real observation data from a freeway in Beijing, China (Li and Lu, 2009). The work in (Xu, Kong, Lin, and Liu, 2012) proposed a spatial prediction approach based on a macroscopic urban traffic network model. This work concentrated on mechanism of vehicles transmission on road segments and the spatial model of the network in addition a speed density model was used to acquire the vehicle travel time in the network. Then, traffic simulation software, CORSIM was used to simulate the real urban traffic. The simulation results of the software produced the effective prediction timings in particular during rush hours and sudden change in traffic states. The work of Jin presented a link queue model of network traffic flow where the changes in the link density describe the different congestion levels on a road link. This model could capture some features of the link traffic flow such as capacity, jam density free-flow speed. When incorporating a junction flux functions it could also describe the propagation, initiation and dissipation of traffic queues within a road network which might be caused by different types of bottlenecks (Jin, 2013).

This paper presents a detailed assessment study of traffic flow within the central area of Madinah along First Ring Road during Hajj and Umrrah seasons to reflect the maximum vehicle flow in this area. The study entailed a comparison among the roads leading to this area in terms of traffic flow nature, peak times, bottlenecks, and traffic distribution. In addition, a new optimization model for the traffic distribution along the roads intersecting with First Ring Road was formulated in order to determine the traffic characteristics on the road network.

The rest of the paper is organized as follows: section 2 describes the methodology and materials, section 3 provides the Results and data verification, section 4 discusses 
the proposed road network model for First Ring Road and the simulation results, and finally section 5 concludes the paper.

\section{METHODOLOGY AND MATERIALS}

Data collection was carried out in the area of study which is First Ring Road surrounding the central area of Madinah. From surveying the area, it is concluded that First Ring Road is accessed by 12 roads which connect to it. Figure 2 shows the location of these roads and Table 2 provides some detailed description for each road.

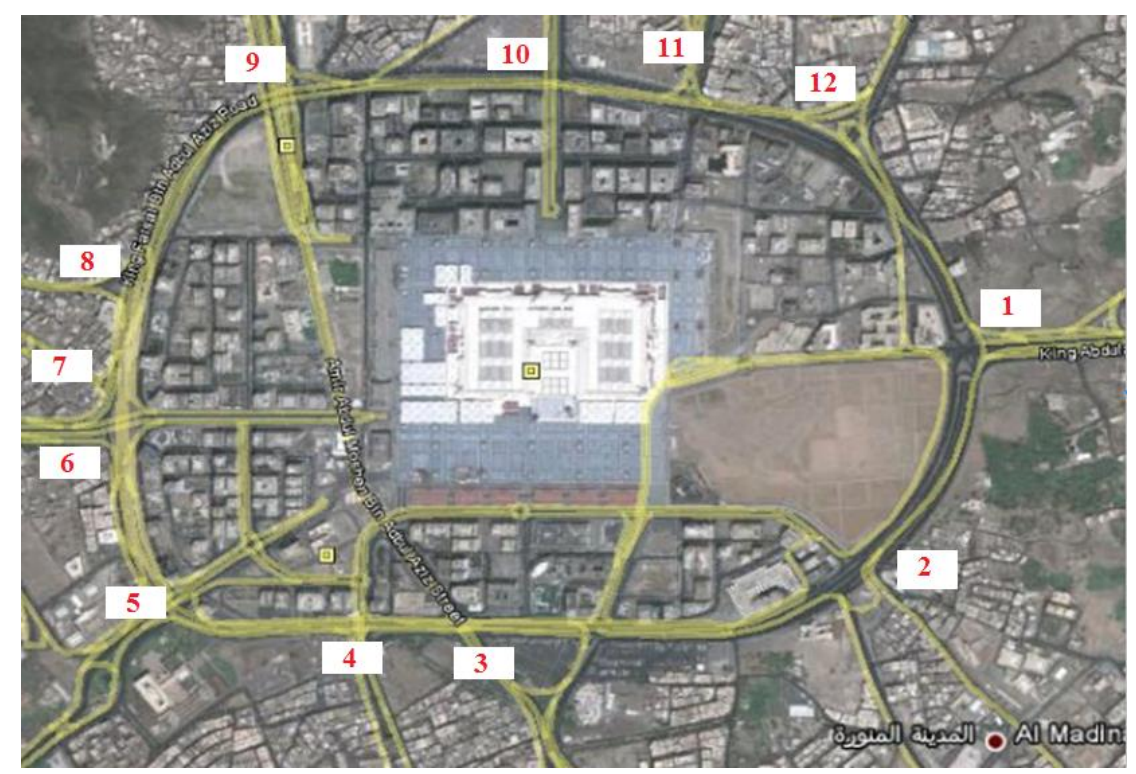

Figure 2. Location of roads (Google Maps, 2013).

Table 2. Description of All Roads Connecting to First Ring Road

\begin{tabular}{|l|l|}
\hline 1. & $\begin{array}{l}\text { King Abdul-Aziz Road: This road extends to } 3 \mathrm{~km} \text { until Second Ring Road at the east } \\
\text { side of Al-Masjid Al-Nabawi. This is a two-way road, leading to and away from Al- } \\
\text { Masjid Al-Nabawi, with three lanes each. It is used as the main entrance for the people } \\
\text { travelling from eastern cities e.g., Riyadh and Qassim. Locally the area around this road is } \\
\text { mainly residential. This road will have a bigger importance in the future when it becomes } \\
\text { the main link between the Knowledge City and Madinah center area. }\end{array}$ \\
\hline 2. & $\begin{array}{l}\text { Ali Ibn AbiTaleb Road: A narrow road with two lanes extends to } 5 \mathrm{~km} \text { to connect the } \\
\text { two ring roads through a heavy residential area in the southern east side of Al-Masjid Al- } \\
\text { Nabawi. }\end{array}$ \\
\hline 3. & $\begin{array}{l}\text { Qurban Road: This road makes the main connection between the two main mosques of } \\
\text { Madinah; Al-Masjid Al-Nabawi and Qubaa. It extends south to } 5 \mathrm{~km} \text { with two lanes } \\
\text { through a heavy residential and shopping area. }\end{array}$ \\
\hline 4. & $\begin{array}{l}\text { Qubaa Road: This road extends for 1.6 km with two lanes through a heavy residential } \\
\text { and shopping area at the south-west direction of Al-Masjid Al-Nabawi. }\end{array}$ \\
\hline
\end{tabular}


Table 2 (Continue)

\begin{tabular}{|c|c|}
\hline 5. & $\begin{array}{l}\text { Omar Ibn Al-Khattab Road: This a vital busy road that extends for about } 1.6 \mathrm{~km} \text { at the } \\
\text { western side of the central area connecting Al-Masjid Al-Nabawi with Second Ring Road. } \\
\text { This road is considered the main Madinah entrance for travelers to and from Makkah. It } \\
\text { is also used heavily by locals due to the fact that the Emarrah (City Hall) is located at its } \\
\text { end at the point it merges with First Ring Road. }\end{array}$ \\
\hline 6. & $\begin{array}{l}\text { Al-Salam Road: This road connects the central area with Second Ring Road until the two } \\
\text { main universities of Madinah, Taibah University and Islamic University of Madinah. } \\
\text { Designed as a highway with three lanes on each side for about } 1.9 \mathrm{~km} \text { until Second Ring } \\
\text { Road. }\end{array}$ \\
\hline 7. & $\begin{array}{l}\text { Alemam Alshafai Street: A one lane road which ends in First Ring Road from AlSeeh } \\
\text { area. It is the road parallel to Al-Salam road in the north side. The traffic flow of this } \\
\text { road is noticed to be continuous at different peak times of the day. }\end{array}$ \\
\hline 8. & $\begin{array}{l}\text { Harb Street: is a two-way street located to the north side of Aleman Alshafai Street in the } \\
\text { Seeh area and connects to First Ring Road. However, this road was not considered in this } \\
\text { study since the traffic flow into the Ring Road is very minimal and is not that significant. }\end{array}$ \\
\hline 9. & $\begin{array}{l}\text { Abu-Bakr Al-Siddiqi Road (currently known as Sultana Road): This road extends } \\
\text { from the central area of Madinah to the main shopping areas at the northwest side Al- } \\
\text { Masjid Al-Nabawi for about } 2.25 \mathrm{~km} \text {. Represented in two directions, leading to and from } \\
\text { the central area, with three lanes each. It is also a main connection to other major roads } \\
\text { going to and leaving the central area which are not connected to First Ring Road (Othman } \\
\text { Ibn Affan Road, Sayeed Alshuhada'a Road, ...). }\end{array}$ \\
\hline 10. & $\begin{array}{l}\text { King Fahd Road: With two directions of three lanes each, this road extends north out of } \\
\text { the central area for about } 2.5 \mathrm{~km} \text { connecting the area with Second Ring Road. Mainly } \\
\text { used by travelers to Makkah. }\end{array}$ \\
\hline 11. & $\begin{array}{l}\text { Abu-Dhar Algefari Road: Abu-Dhar Algefari Road extends between First and Second } \\
\text { Ring Roads and passes through the taxi station and bus station (SAPTCO) area. During } \\
\text { the peak seasons of Hajj and Umrah, the section between Airport Road and First Ring } \\
\text { Road is blocked for traffic flowing into the central area in order to reduce the traffic flow } \\
\text { in First Ring Road. Therefore, this road was not considered in this study since the flow of } \\
\text { vehicles into First Ring Road is not significant and is diverted to King Fahd Road and } \\
\text { Airport Road. }\end{array}$ \\
\hline 12. & $\begin{array}{l}\text { Alabbas Ibn Abdul Mutalib Street: This road connects the central area with the Airport } \\
\text { Road at the northeast side of Al-Masjid Al-Nabawi. It extends for } 3.3 \mathrm{~km} \text { between the } \\
\text { central area and Second Ring Road. Designed to take from and to the airport with three } \\
\text { lanes on each side, it passes through crowded residential and shopping areas. }\end{array}$ \\
\hline
\end{tabular}

Vehicle count data collection is divided into 3 parts as follows:

1. MetroCount traffic survey systems (automatic vehicle counts) placed on main roads connecting to the central area of Madinah were used to automatically count the number of vehicles going in and out of First Ring Road of Madinah surrounding AlMasjid Al-Nabawi.

2. Manual vehicle counts were carried out by subjects (students) using hand-held counters, on the secondary roads connecting to the central area.

3. Manual Vehicle counts at major 3-way and 4-way intersections conducted by subjects to count the number of vehicles in different directions of the 3-way and 4way intersections. These intersections are junctions of King AbdulAziz Road, Omar Ibn AlKhattab Road, Quba'a Road, Qurban Road and Abu-Bakr Al-Siddiqi Road with First Ring Road. 
For the automatic vehicle counts, data collection was limited to five roads only due to the scarcity of metroCounters and the limited project budget. After surveying the area under study, the five busiest roads were identified then the metroCounters were placed on the following roads: King AbdulAziz Road, Ali Ibn AbiTableb, Omar Ibn AlKhattab, Abu-Bakr Al-Siddiqi Road and King Fahd Road. The manual count was used with the rest of the roads.

\section{RESULTS}

\section{Automatic Ingoing Vehicle Counts}

From the data collected using the metroCounters on the major roads all roads surveyed throughout the day appear to have the same trend (behavior) as shown in Figure 3. Therefore, the average of the data collected from all days for all roads is calculated. Figure 3 combines the hourly average number of vehicles travelling over different days in 24 hours on all roads measured using metroCounters. The graphs show a similar trend in traffic flow on all the roads connecting to First Ring Road; however, with different traffic flow rates since this depends on the number of vehicles traveling from the different parts of the city into the central area.

\section{Automatic Out-Going Vehicle Counts}

The roads surveyed for the ingoing vehicle flow into the central area of Madinah were also surveyed for the out-going vehicle flow except for Ali Ibn AbiTaleb Road which is a one-way street flowing into First Ring Road. The average vehicle flow traveling out of the central area of town during 24 hours of the day from the four roads measured using metroCounters is shown in Figure 4. It is very clear from the graphs that the trend for the outgoing traffic flow is similar for all the roads surveyed and this observation can be applied to all outgoing traffic for all other roads not surveyed.

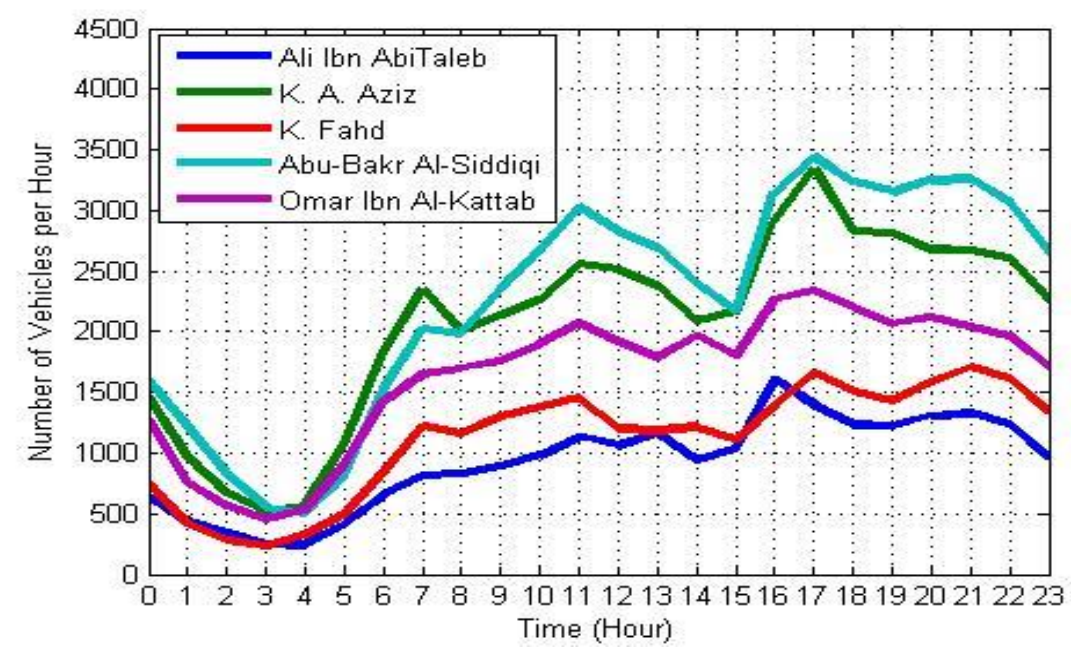

Figure 3. Average number of vehicles travelling over different days in $24 \mathrm{hrs}$. on all Roads 


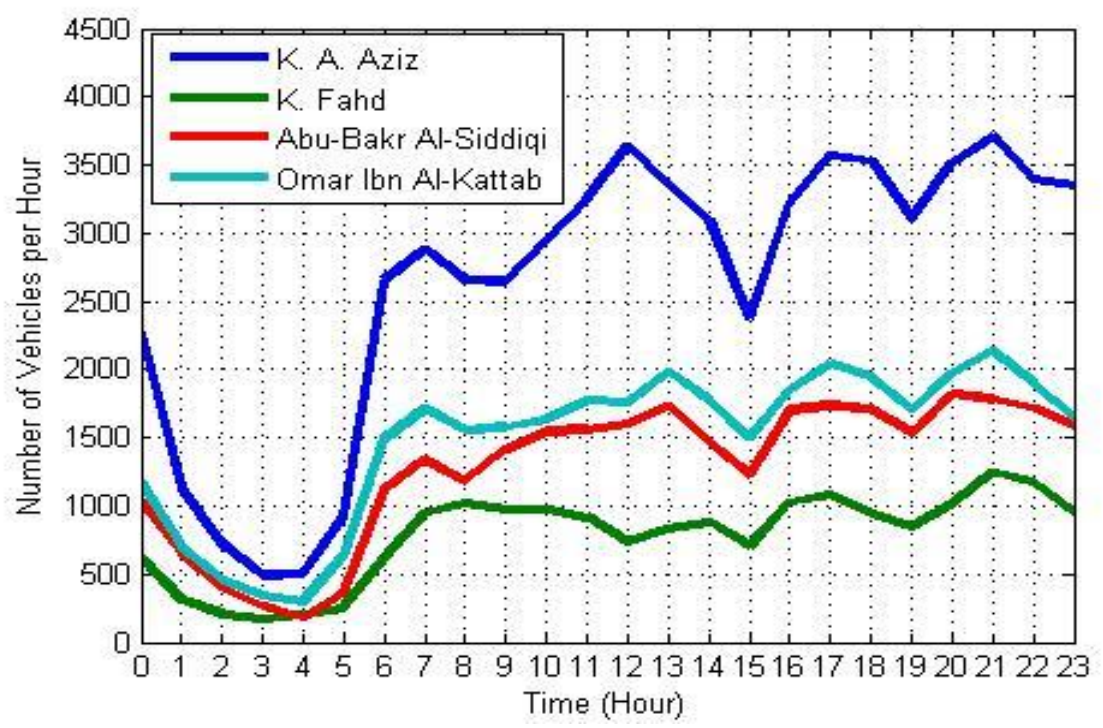

Figure 4. Average number of vehicles travelling over different days in $24 \mathrm{hrs}$ on all roads.

\section{Manual Vehicle Counts}

With the aid of a group of students from the college of computer science and engineering at Taibah University the number of vehicles from the secondary roads (not surveyed using metroCounters) flowing into First Ring Road were counted using manual hand counters. The data was collected at different times and days during the Hajj season before and after the Hajj days. It was very difficult managing the data collection process at the same time for all the roads. Therefore, the average number of vehicles was calculated for all the secondary streets flowing into First Ring Road between 8:00 A.M. and 9:00 P.M. The manual count did not consider the times between 9:00 P.M. until 8:00A.M. and this could be a limitation in this study due to the fact that only 5 metroCounters were approved for this study and it was difficult to have the students available all the time during the day and night hours. This part of data collection was combined with the metroCounters in order to determine the total number of vehicles using First Ring Road between 8:00 A.M. and 9:00 P.M. Table 3 shows the data collected from all roads surveyed between 8:00 A.M. and 9:00 P.M.

From the data provided in Table 3, Figure 5 presents the graphs for the average vehicle count for all roads separately. From this figure, the traffic flow is not uniform for all the roads and different behavior is noticed. Most roads show the same behavior of the average vehicle count of all streets shown in Figure 5, with the exception of Quba'a Street and K. Fahd exit ramp that flows into First Ring Road. Most of the roads show the PM peak between 4:00 and 5:00 P.M. which is confirmed from the average vehicle count for all roads shown in Figure 6. On the other hand, the AM peak time is around 12:00 noon. The peak average vehicle count is approximately 2000 vehicles and the average hourly vehicle flow is 17,495 vehicles/hour. The traffic flow is shown to increase from the middle of the morning rush hour at 8:00 A.M. until around noon time then it slightly decreases. It starts to pick up around 3:00 P.M. after that it peaks around 5:00 P.M. after which the traffic decreases until probably the early morning hours where it starts increasing again. 
Table 3. Average hourly data for all roads connecting to First Ring Road between 8:00 A.M. to 9:00 P.M.

\begin{tabular}{|c|c|c|c|c|c|c|c|c|c|c|c|c|}
\hline & $\begin{array}{c}\text { Alemam } \\
\text { Alshafai } \\
\text { St }\end{array}$ & $\begin{array}{c}\text { Al- } \\
\text { Salam }\end{array}$ & Quba'a & Qurban & $\begin{array}{c}\text { Ali Ibn } \\
\text { AbiT } \\
\text { aleb }\end{array}$ & $\begin{array}{c}\text { King } \\
\text { Abdul- } \\
\text { Aziz }\end{array}$ & $\begin{array}{l}\text { Alabbas } \\
\text { Ibn Abdul } \\
\text { Mutalib }\end{array}$ & $\begin{array}{c}\text { K. } \\
\text { Fahd }\end{array}$ & $\begin{array}{l}\text { K. } \\
\text { Fahd } \\
\text { exit - } \\
\text { ramp }\end{array}$ & $\begin{array}{c}\text { Abu } \\
\text { Bakr } \\
\text { Al- } \\
\text { Siddiqi }\end{array}$ & $\begin{array}{l}\text { Omar } \\
\text { Ibn Al- } \\
\text { Khattab }\end{array}$ & Total \\
\hline 08:00 & 1875 & 1389 & 914 & 1762 & 819 & 2008 & 832 & 1149 & 155 & 1989 & 1736 & 14625 \\
\hline 09:00 & 1723 & 1512 & 908 & 1469 & 879 & 2058 & 637 & 1269 & 228 & 2239 & 1758 & 14678 \\
\hline 10:00 & 2011 & 1642 & 896 & 1223 & 953 & 2211 & 817 & 1347 & 319 & 2606 & 1856 & 15880 \\
\hline 11:00 & 1822 & 1369 & 878 & 1349 & 1069 & 2450 & 710 & 1449 & 444 & 2952 & 2040 & 16532 \\
\hline 12:00 & 2144 & 1951 & 886 & 1241 & 1121 & 2643 & 807 & 1274 & 320 & 2947 & 2035 & 17369 \\
\hline 13:00 & 2414 & 1702 & 897 & 1165 & 1146 & 2408 & 786 & 1152 & 305 & 2718 & 1851 & 16545 \\
\hline 14:00 & 2273 & 1789 & 853 & 1085 & 993 & 2179 & 742 & 1230 & 262 & 2468 & 1962 & 15834 \\
\hline 15:00 & 2185 & 2008 & 837 & 1952 & 970 & 2142 & 657 & 1140 & 269 & 2193 & 1800 & 16152 \\
\hline 16:00 & 2693 & 2022 & 1246 & 1788 & 1504 & 2657 & 852 & 1283 & 292 & 2841 & 2166 & 19344 \\
\hline 17:00 & 2477 & 2151 & 1840 & 1594 & 1547 & 3315 & 948 & 1646 & 358 & 3522 & 2378 & 21776 \\
\hline 18:00 & 2471 & 2219 & 1806 & 1306 & 1150 & 2853 & 808 & 1487 & 342 & 3126 & 2219 & 19789 \\
\hline 19:00 & 2170 & 2063 & 1783 & 1594 & 1271 & 2995 & 751 & 1522 & 381 & 3323 & 2138 & 19990 \\
\hline 20:00 & 2357 & 2096 & 1630 & 1306 & 1263 & 2619 & 684 & 1474 & 274 & 3113 & 2101 & 18915 \\
\hline \multicolumn{12}{|c|}{ Total average number of vehicles into First Ring Road from all roads between 8:00 A.M. and 9:00 P.M. } & 227428 \\
\hline
\end{tabular}

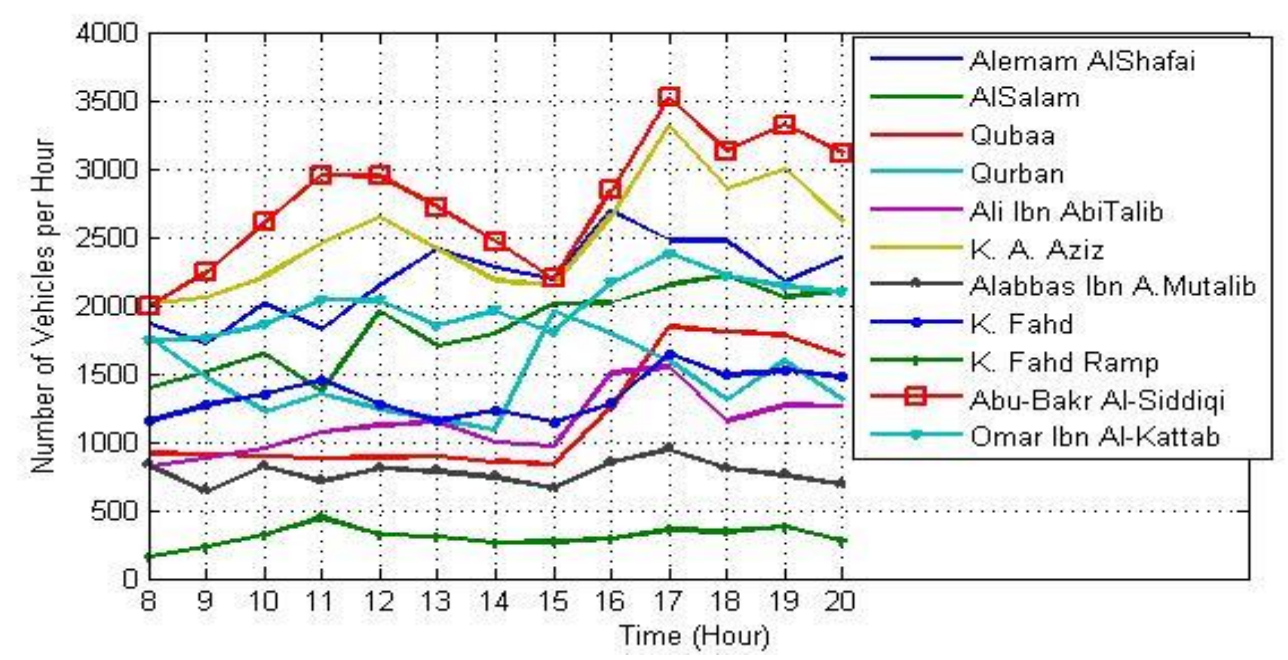

Figure 5. Hourly traffic behavior for all roads between 8:00 A.M. and 9:00 P.M.

The total amount of traffic flowing into First Ring Road between 8:00 A.M. - 9:00 P.M. is 227,429 vehicles. This shows that the total number of vehicles flowing into First Ring Road could exceed the 350,000 vehicles/day in a 24-hour period. Table 4 shows the average vehicle count in an interval of 15 minutes between 7:30 - 7:45 P.M. The two main roads which contribute to a total highest percentage flow of $32 \%$ are King AbdulAziz Road and Abu-Bakr Al-Siddiqi Road with approximately 16\% each. The other three roads contributing approximately $33 \%$ of the traffic flow, each approximately $11 \%$, are Alemam Alshafai Street, Omar Ibn Al-Khattab Road and AlSalam Road. Therefore, four of these roads confirm to the choice of the busiest roads chosen for the automatic traffic count and the only road which did not confirm with the findings is Ali Ibn Abi-Taleb Road. The central Madinah enclosed by First Ring Road was divided into 5 different areas as shown in Figure 7. 


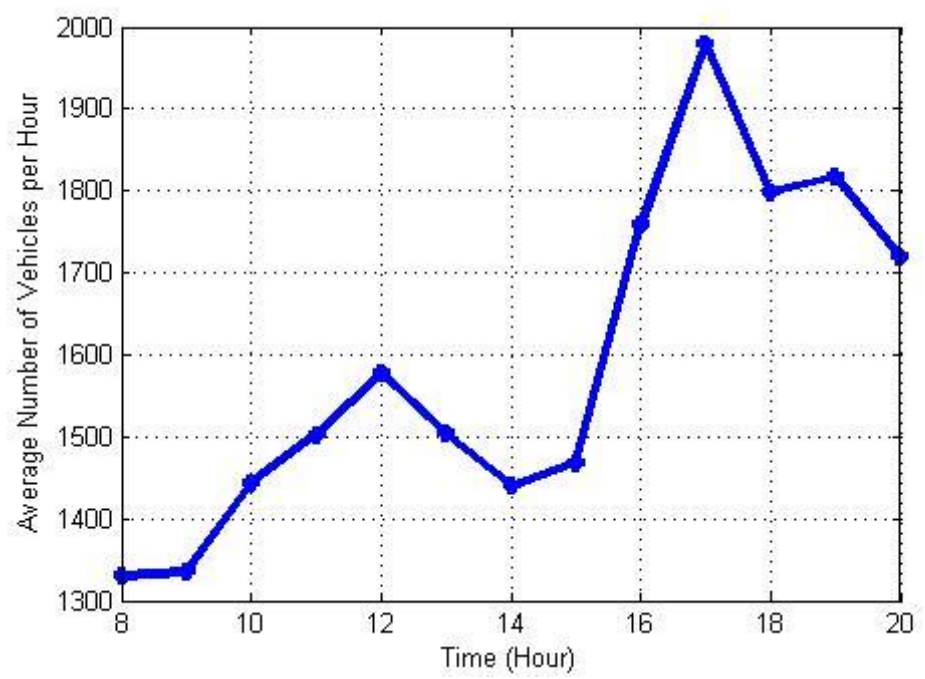

Figure 6. Average hourly traffic behavior for all roads between 8:00 A.M. and 9:00 P.M.

Table 4. Percentage traffic flow during the peak average time using 15 minutes interval.

\begin{tabular}{|c|c|c|}
\hline Name of the Road & Peak & $\%$ \\
\hline King Abdul Aziz Road & 928 & 16.4 \\
\hline Ali Taleb & 387 & 6.8 \\
\hline Qurban & 344 & 6.1 \\
\hline Quba & 450 & 8 \\
\hline Omar Ibn Al-Khattab & 624 & 11 \\
\hline Al-Salam & 579 & 10.2 \\
\hline Alemam Alshafai St & 648 & 11.5 \\
\hline $\begin{array}{c}\text { Abu-Bakr Al-Siddiqi } \\
\text { Road }\end{array}$ & 909 & 16.1 \\
\hline King Fahd ramp & 92 & 1.6 \\
\hline King Fahd & 456 & 8.1 \\
\hline $\begin{array}{c}\text { Alabbas Ibn Abdul } \\
\text { Mutalib Street }\end{array}$ & 236 & 4.2 \\
\hline Total & 5653 & $100 \%$ \\
\hline
\end{tabular}

The traffic flow between King AbdulAziz Road and Abu Bakr Al-Siddiq Road shows the busiest section of First Ring Road, contributing approximately $46.4 \%$ of the traffic flow in the area as presented in Table 5. This section of First Ring Road contributes about 1/3 of Ring Road and therefore, the reasons for the highest traffic flow in this section of First Ring Road are: it contains two major roads connecting to First Ring Road, heavily populated area with many hotels; it has close proximity to Second Ring Road which can be accessed from many other streets in the area; it contains some old residential parts of Madinah; finally it is the location of many businesses and service areas such as a hospital, bus terminal etc. The outgoing and ingoing traffic were compared by considering the total average traffic flow for all days surveyed from the four main roads using the metroCounters data collected during the 24-hour period. Table 6 shows the comparison for the only four roads surveyed for both ingoing and outgoing traffic. 


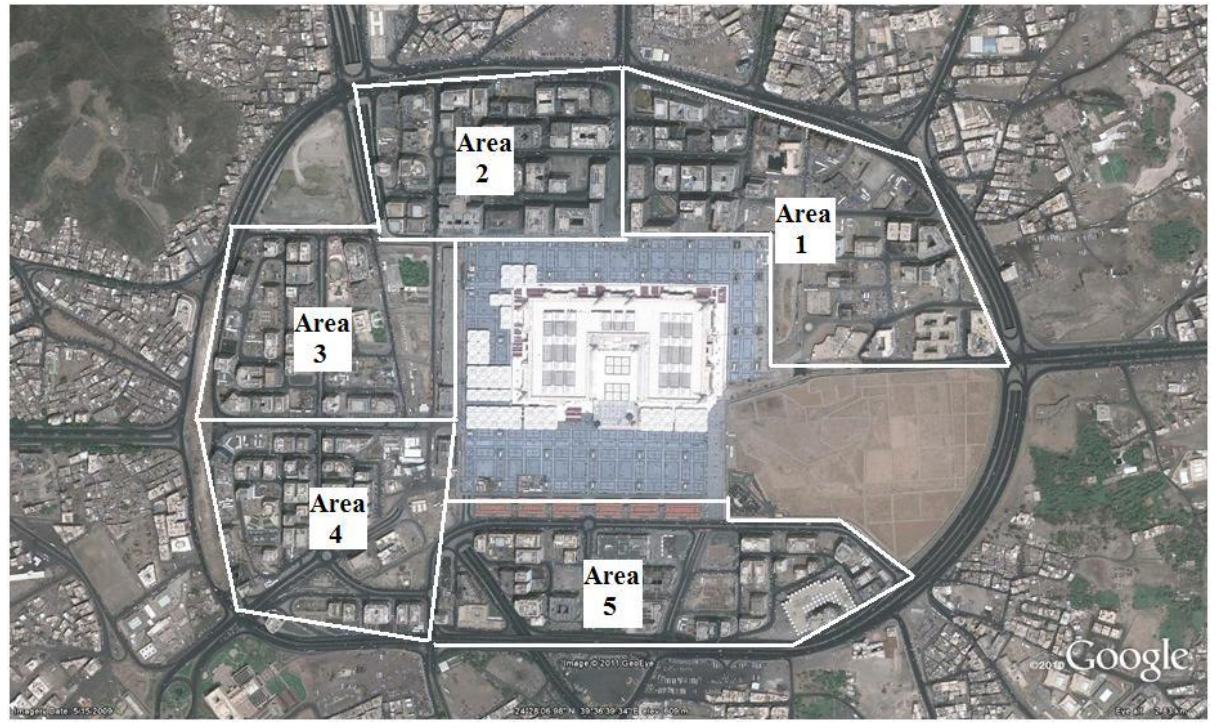

Figure 7. The central area of Madinah divided into five different sections (Google Maps, 2013)

Table 5. Percentage traffic flow according to different areas on First Ring Road

\begin{tabular}{|c|l|c|}
\hline Area & \multicolumn{1}{|c|}{ Location } & $\begin{array}{c}\text { Percentage of } \\
\text { Traffic Flow }\end{array}$ \\
\hline 1 & $\begin{array}{l}\text { King Abdul-Aziz Road + Alabbas Ibn Abdul Mutalib } \\
\text { Street + King Fahd Road }\end{array}$ & $28.7 \%$ \\
\hline 2 & King Fahd (ramp) + Abu Bakr Al-Siddiq & $17.7 \%$ \\
\hline 3 & Alemam Alshafai St + Al-Salam Road & $21.7 \%$ \\
\hline 4 & Omar Ibn Al-khattab Road & $11.0 \%$ \\
\hline 5 & Quba'a + Qurban + Ali Ibn Abi-Taleb & $20.9 \%$ \\
\hline
\end{tabular}

Table 6. Ingoing and outgoing traffic comparison

\begin{tabular}{|l|c|c|c|c|c|}
\hline & $\begin{array}{c}\text { King } \\
\text { AbdulAziz }\end{array}$ & $\begin{array}{c}\text { King } \\
\text { Fahd } \\
\text { Road }\end{array}$ & $\begin{array}{c}\text { Abu-Bakr } \\
\text { Al-Siddiqi } \\
\text { Road }\end{array}$ & $\begin{array}{c}\text { Omar Ibn } \\
\text { Al-Khattab }\end{array}$ & Total \\
\hline $\begin{array}{l}\text { Total average outgoing } \\
\text { traffic flow (Out) }\end{array}$ & 55532 & 18642 & 30697 & 35605 & 140476 \\
\hline $\begin{array}{l}\text { Total average ingoing } \\
\text { traffic flow (In) }\end{array}$ & 49763 & 20833 & 54403 & 39337 & 164336 \\
\hline Ratio (Out/In) & 111.593 & 89.483 & 56.4252 & 90.5127 & 85.481 \\
\hline$\frac{(\text { Out/Total In) }}{\text { Total Ratio(Out/In) }}$ & 0.395313 & 0.132706 & 0.218521 & 0.25346 & 100 \\
\hline
\end{tabular}

From Table 6 it is very clear that King Abdul Aziz Road followed by Omar Ibn Al-Khattab Road takes the most of the traffic out of the central area of Madinah. Their proximity to Second Ring Road which provides an easy exit from the area can be a main reason for that. Another reason might be the fact that the traffic from Al-Masjid AlNabawi's underground parking lot is directed through them. Also, it is noticed that traffic is flowing smoothly on these two roads due to minimum number of traffic lights installed. However, Abu-Bakr Al-Siddiqi Road has a moderate outgoing flow of traffic 
since it passes through a heavy business and residential area. Thus, the people avoid using it to go to Second Ring Road. On the other hand, King Fahd Road has the lowest outgoing traffic since it does not directly meet Second Ring Road as well as it does not have a direct connection with Al-Masjid Al-Nabawi parking lot.

\section{Traffic Diversion on First Ring Road}

The main roads in Madinah end at First Ring Road. From the main road, vehicles can turn right, left to First Ring Road or straight into the central area. A pilot study was performed to determine how much percentage of the total traffic is diverted to either of these directions. It has also been noticed that the majority of traffic represents a counterclockwise traffic nature for the whole area as shown in Table 7.

Table 7. Percentage traffic diversion from First Ring Road

\begin{tabular}{|c|c|c|c|}
\hline Road Name & Left & Right & straight \\
\hline King Abdul-Aziz & 65 & 21 & 14 \\
\hline Ali Ibn Abi-Taleb & 0 & 100 & 0 \\
\hline Qurban & 0 & 30 & 70 \\
\hline Quba & 0 & 40 & 60 \\
\hline Omar Ibn Al-Khattab & 41 & 49 & 10 \\
\hline Al-Salam & 0 & 100 & 0 \\
\hline Alemam Alshafai Street & 0 & 100 & 0 \\
\hline Abu-Bakr Al-Siddiqi Road & 0 & 55 & 45 \\
\hline King Fahd ramp & 0 & 100 & 0 \\
\hline King Fahd Road & 0 & 100 & 0 \\
\hline $\begin{array}{c}\text { Alabbas Ibn Abdul Mutalib } \\
\text { Street }\end{array}$ & 0 & 100 & 0 \\
\hline
\end{tabular}

Table 7 shows that with the exception of some roads leading to the left direction. King AbdulAziz directs $65 \%$ of the traffic to the left, $21 \%$ to the right and, $14 \%$ straight. From Omar Ibn Al-khattab road, $49 \%$ of vehicles turn right, $41 \%$ left, and $10 \%$ move straight into Al-Masjid Al-Nabawi area. Quba'a road directs 60\% of its traffic towards Al-Masjid Al-Nabawi area and 40\% to the right on First Ring Road. 30\% of Qurban road traffic is directed to the right while the rest flows straight towards the tunnel. 55\% of traffic of Abu-Bakr Al-Siddiqi Road flows to the right on First Ring Road and $45 \%$ is discharged through the tunnel. Alabbas Ibn Abdul Mutalib Street, Abu Dhar Algefari and King Fahd roads are all located close to each other (within about 600 m). Beside pedestrians-crossing portions of First Ring Road become the busiest area causing high traffic congestion. Same phenomenon is noticed at Alemam Alshafai Street, Al-Salam Road and Omar Ibn Al khattab Road which are located within a distance of $430 \mathrm{~m}$.

\section{Data Verification}

In this section, we performed data verification by statistical analysis. Table 7 presents the sample data of all averages of traffic flow from 8:00 AM to 9:00 PM for all streets. A two-way analysis (row- and column-wise) of variance is conducted using the statistical software Anova to test the interaction between streets at different times of the 
day provided in Table 8. Anova calculates the total sum of squares values (SS), degree of freedom (DF), mean square (MS), F statistics (F-value), probability (P-value) and critical $F$ value (F crit). Detail explanation of these terms can be found in any standard book of statistics. The P-value of the test represents a significance difference between streets and between times of the day. Based on the computed F-value we conclude that at least one non-zero interaction effect exists for at least one treatment (cell). Since the computed value exceeds the critical, the null hypothesis of no main effects from time of the day of traffic flow must be rejected at $\mathrm{P}=0.05$. Also, the computed value of $\mathrm{F}=162.46$ leads to rejection of null hypothesis of identical mean traffic volume for all streets.

A correlation test resulted in a high positive correlation between streets especially those with high traffic volume representing a linear relationship between the streets traffic volume and the time of the day. Although the results do not reveal the main reason for this high correlation between streets, it can be related to either the traffic volume of these streets, to the proximity nature of the streets, or to both reasons as in the case of Abu Bakr and K. AbdulAziz, and K. AbdulAziz and Omar Ibn Alkattab, given in Table 9.

Table 8. Two-way ANOVA results

\begin{tabular}{|c|c|c|c|c|c|c|}
\hline $\begin{array}{c}\text { Source of } \\
\text { Variation }\end{array}$ & SS & DF & MS & F-value & P-value & F crit \\
\hline Rows & 5490993 & 12 & 457582.8 & 10.17288 & $1.51 \mathrm{E}-13$ & 1.833695276 \\
\hline Columns & 73079928 & 10 & 7307993 & 162.4696 & $8.49 \mathrm{E}-65$ & 1.910461065 \\
\hline Error & 5397680 & 120 & 44980.67 & & & \\
\hline Total & 83968602 & 142 & & & & \\
\hline
\end{tabular}

Table 9. Correlation results

\begin{tabular}{|c|c|c|c|c|c|c|c|c|c|c|c|}
\hline & $\begin{array}{c}\text { Alemam } \\
\text { Alshafai } \\
\text { St }\end{array}$ & $\begin{array}{c}\text { Al- } \\
\text { Salam }\end{array}$ & Quba'a & Qurban & $\begin{array}{c}\text { Ali Ibn } \\
\text { AbiTaleb }\end{array}$ & $\begin{array}{c}\text { King } \\
\text { Abdul- } \\
\text { Aziz }\end{array}$ & $\begin{array}{c}\text { Alabbas } \\
\text { Ibn } \\
\text { Abdul } \\
\text { Mutalib }\end{array}$ & $\begin{array}{c}\text { King } \\
\text { Fahd }\end{array}$ & $\begin{array}{c}\text { King } \\
\text { Fahd } \\
\text { exit } \\
\text { ramp }\end{array}$ & $\begin{array}{c}\text { Abu } \\
\text { Bakr } \\
\text { Al- } \\
\text { Siddiqi }\end{array}$ & $\begin{array}{c}\text { Omar } \\
\text { Ibn Al- } \\
\text { Khattab }\end{array}$ \\
\hline $\begin{array}{c}\text { Alemam } \\
\text { Alshafai St }\end{array}$ & 1.00 & & & & & & & & & & \\
\hline Al-Salam & 0.79 & 1.00 & & & & & & & & & \\
\hline Quba'a & 0.53 & 0.73 & 1.00 & & & & & & & & \\
\hline Qurban & 0.03 & 0.12 & 0.11 & 1.00 & & & & & & & \\
\hline $\begin{array}{c}\text { Ali Ibn } \\
\text { AbiTaleb }\end{array}$ & 0.78 & 0.69 & 0.69 & 0.13 & 1.00 & & & & & & \\
\hline $\begin{array}{c}\text { King Abdul- } \\
\text { Aziz }\end{array}$ & 0.59 & 0.72 & 0.85 & 0.01 & 0.87 & 1.00 & & & & & \\
\hline $\begin{array}{c}\text { Alabbas Ibn } \\
\text { Abdul } \\
\text { Mutalib }\end{array}$ & 0.49 & 0.25 & 0.35 & 0.04 & 0.53 & 0.54 & 1.00 & & & & \\
\hline King Fahd & 0.22 & 0.46 & 0.83 & -0.11 & 0.62 & 0.83 & 0.31 & 1.00 & & & \\
\hline $\begin{array}{c}\text { King Fahd } \\
\text { exit - ramp }\end{array}$ & 0.15 & 0.24 & 0.35 & -0.25 & 0.47 & 0.63 & 0.13 & 0.66 & 1.00 & & \\
\hline $\begin{array}{c}\text { Abu Bakr } \\
\text { Al- Siddiqi }\end{array}$ & 0.51 & 0.63 & 0.79 & -0.22 & 0.81 & 0.95 & 0.41 & 0.87 & 0.76 & 1.00 & \\
\hline $\begin{array}{c}\text { Omar Ibn } \\
\text { Al-Khattab }\end{array}$ & 0.65 & 0.71 & 0.81 & -0.04 & 0.87 & 0.94 & 0.52 & 0.83 & 0.62 & 0.92 & 1.00 \\
\hline
\end{tabular}




\section{DISCUSSION OF PROPOSED MODEL OF FIRST RING ROAD}

\section{Proposed Model}

In this section, we present a new model for evaluating the traffic flow on First Ring Road. The proposed model was built using a linear least square method with constraints. The linear least square was formulated by the problem of minimizing the difference between the calculated number of vehicles moving out of Ring Road and the corresponding measured number of outgoing vehicles. Observe that the number of vehicles entering at various intersections of Ring Road is obtained from measurement data. Then according to the locations of traffic intersections, the vehicles are accumulated on the ring road or the portions of vehicles are diverted by moving out of Ring Road. The number of vehicles moving out of Ring Road can be computed as follows.

The vehicles from roads flowing from twelve connecting roads travel along First Ring Road and finally move out of Ring Road (exits). Assume that $I_{1}, I_{2}, \ldots I_{n}$ are the number of vehicles entering Ring Road and $E_{1}, E_{2}, \ldots, E_{n}$ are the number of vehicles moving out of Ring Road. Vehicles are randomly passing out of Ring Road from exits. The fractions $r_{2} x_{2}, r_{3} x_{3}, \ldots r_{n} x_{n}$ of vehicles that pass through exits where $r_{2}, r_{3}, \ldots r_{n}$ are random numbers. The values of $x_{2}, x_{3}, \ldots, x_{n}$ are computed in a way such that the following condition holds:

$$
r_{2} x_{2} I_{j}+r_{3} x_{3} I_{j}+\ldots+r_{n} x_{n} I_{j}=I_{j}
$$

for $j=1,2, \ldots, n$ which can be simplified as

$$
r_{2} x_{2}+r_{3} x_{3}+\ldots+r_{n} x_{n}=1
$$

Now, the general relation with input and output can be given as follows

$$
\begin{aligned}
& r_{2} x_{2} \mathrm{I}_{\mathrm{n}}+r_{3} x_{3} \mathrm{I}_{\mathrm{n}-1}+\ldots+r_{n-1} x_{n-1} \mathrm{I}_{3}+r_{n} x_{n} \mathrm{I}_{2}=\mathrm{E}_{1} \\
& r_{2} x_{2} \mathrm{I}_{1}+r_{3} x_{3} \mathrm{I}_{\mathrm{n}}+\ldots+r_{n-1} x_{n-1} \mathrm{I}_{4}+r_{n} x_{n} \mathrm{I}_{3}=\mathrm{E}_{2} \\
& \vdots \\
& r_{2} x_{2} \mathrm{I}_{\mathrm{n}-2}+r_{3} x_{3} \mathrm{I}_{\mathrm{n}-3}+\ldots+r_{n-1} x_{n-1} \mathrm{I}_{1}+r_{n} x_{n} \mathrm{I}_{\mathrm{n}}=\mathrm{E}_{\mathrm{n}-1} \\
& r_{2} x_{2} \mathrm{I}_{\mathrm{n}-1}+r_{3} x_{3} \mathrm{I}_{\mathrm{n}-2}+\ldots+r_{n-1} x_{n-1} \mathrm{I}_{2}+r_{n} x_{n} \mathrm{I}_{1}=\mathrm{E}_{\mathrm{n}}
\end{aligned}
$$

The above equations can be written in matrix vector format $\mathrm{Ax}=\mathrm{E}$.

$$
\underbrace{\left[\begin{array}{ccccc}
r_{2} I_{n} & r_{3} I_{n-1} & & r_{n-1} \mathrm{I}_{3} & r_{n} \mathrm{I}_{2} \\
r_{2} \mathrm{I}_{1} & r_{3} \mathrm{I}_{\mathrm{n}} & \cdots & r_{n-1} \mathrm{I}_{4} & r_{n} \mathrm{I}_{3} \\
& \vdots & & \vdots & \vdots \\
r_{2} \mathrm{I}_{\mathrm{n}-2} & r_{3} \mathrm{I}_{\mathrm{n}-3} & & r_{n-1} \mathrm{I}_{1} & r_{n} \mathrm{I}_{\mathrm{n}} \\
r_{2} \mathrm{I}_{\mathrm{n}-1} & r_{3} \mathrm{I}_{\mathrm{n}-2} & \cdots & r_{n-1} \mathrm{I}_{2} & r_{n} \mathrm{I}_{1}
\end{array}\right]}_{A} \underbrace{\left[\begin{array}{c}
x_{2} \\
x_{3} \\
\vdots \\
x_{n-1} \\
x_{n}
\end{array}\right]}_{x}=\underbrace{\left[\begin{array}{c}
E_{1} \\
E_{2} \\
\vdots \\
E_{n-1} \\
E_{n}
\end{array}\right]}_{E}
$$

Note that the above system is over determined system which can only be solved using least square method using the constraint given in eq. (4). The constraints which have to be imposed is

$$
x_{i} \geq 0
$$


for $i=1,2, \ldots n$. The model of the traffic flow on First Ring Road is solved using Algorithm 1 which uses the Matlab function lsqlin. The algorithm least square problem with the form

$$
\min _{\mathrm{x}} \frac{1}{2}\|A x-E\|^{2} \text { subject to } C x \leq d
$$

can be solved using the function lsqlin.

$$
x=\operatorname{lsq} \operatorname{lin}(A, E, C, d) \text {; }
$$

Algorithm 1 uses the number $I_{i}$ of vehicles entering the ring road and the number $E_{i}$ of vehicles exiting the ring road for $i=1,2, \ldots n$. The algorithm requires randomly generated number $r_{i}$ in the range of $[0,1]$. The output of the algorithm is the traffic distribution $x_{i}$ along the roads intersecting with Ring Road. The algorithm first builds the matrix $A$ of equation (3) and then the terms $C$ and $d$ of equation (5) are formulated. Then function (6) is used to compute $x$.

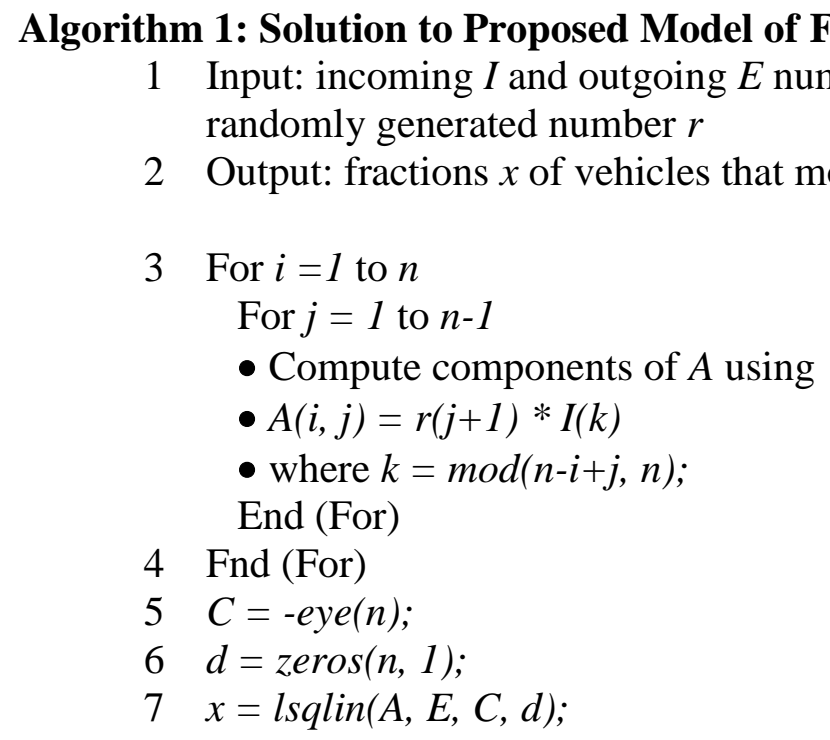

\section{Simulation Results and Discussion}

The computational results from the simulation and the measured result are shown in Figures 8 to 12 . The figures show the number of vehicles per 15 minutes interval moving out of different roads from 8:00 to 21:00 $\mathrm{H}$. Two plots are made in each figure where the number of vehicles moving out of ring road obtained from simulation of computational model and the measured number of vehicles using machines are shown. These results demonstrate good agreements between simulation and measured data. Observe that Figures 8 and 12 show quite good results. Figures 9 - 11 provide some reasonable results due to the random pattern of vehicle movements. The parameters identified from simulation can be later used to predict vehicle movements in Ring Road.

Daily readings taken once per week cannot be relied on for solid conclusion. Students' timetable was another shortcoming to this study. Students were not able to cover all day traffic limiting the data collection to limited hours of the day compared to other data that was taken automatically. Despite the fact that the study was performed 
during a short period of time that may not indicate the real behavior of the traffic over the whole year, it provides a clear insight of traffic flow behavior. However, we recommend that more data for the same time periods to be taken to consolidate the findings.

A general observation that was drawn from the study is that all streets follow the same pattern in terms of traffic behavior despite the difference in their traffic volume. The fact that some roads are located close to each other (within about 450-600 m) and flowing into the same direction resulted in high volume of traffic within some portions of Ring Road. When pedestrians' main crossing areas are added to the mentioned case, the traffic problem will increase. The study revealed the streets with high and low volume of traffic, area design deficiencies, and the need for some rearrangements to the area in order to ease the traffic congestion. Implementation of such measures should not be delayed since the number of vehicles is escalating annually.

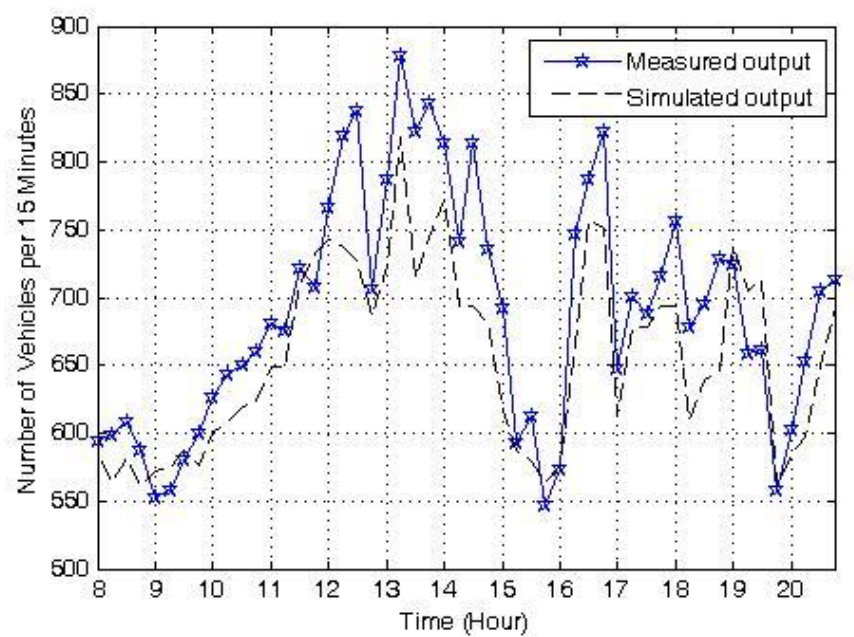

Figure 8. Average number of vehicles travelling over different days from 8:00 to 21:00 at King AbdulAziz Road

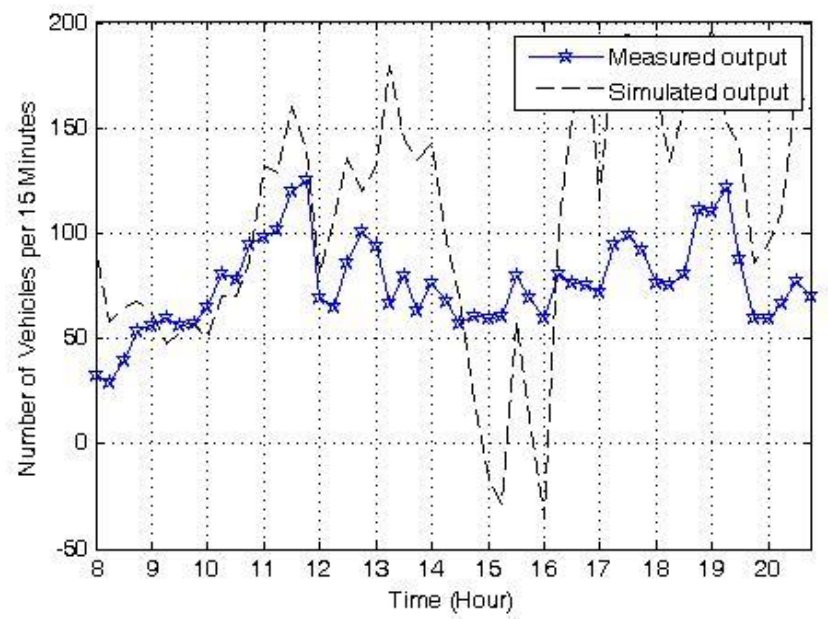

Figure 9. Average number of vehicles travelling over different days from 8:00 to 21:00 at King Fahd exit (Ramp) 


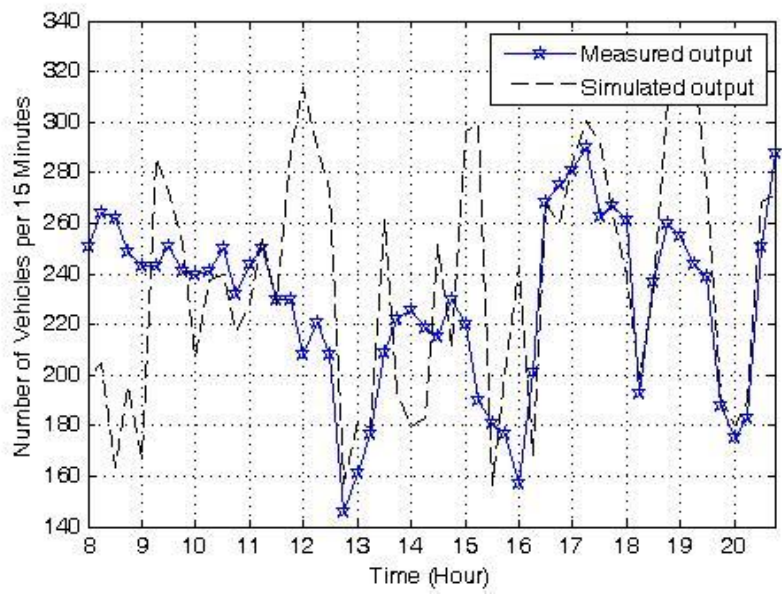

Figure 10. Average number of vehicles travelling over different days from 8:00 to 20:45H at King Fahd Road

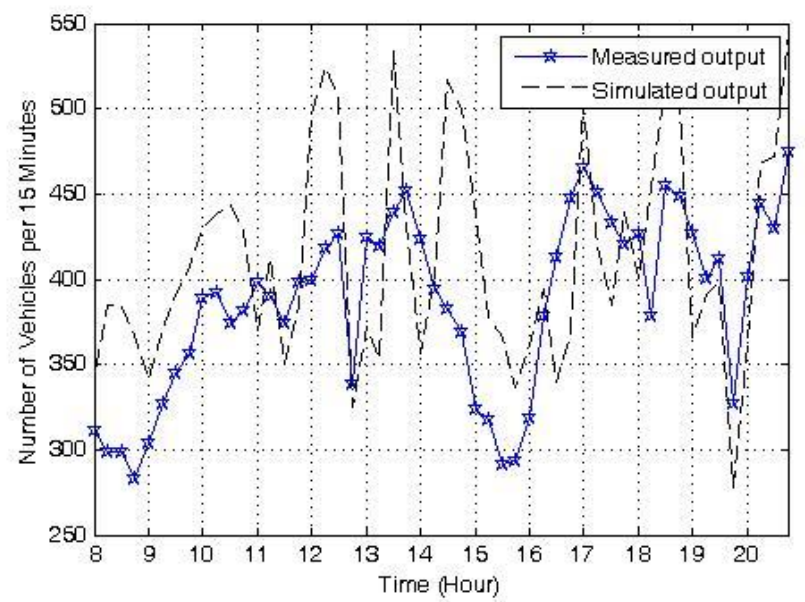

Figure 11. Average number of vehicles travelling over different days from 8:00 to 21:00 at Abu Bakr Road

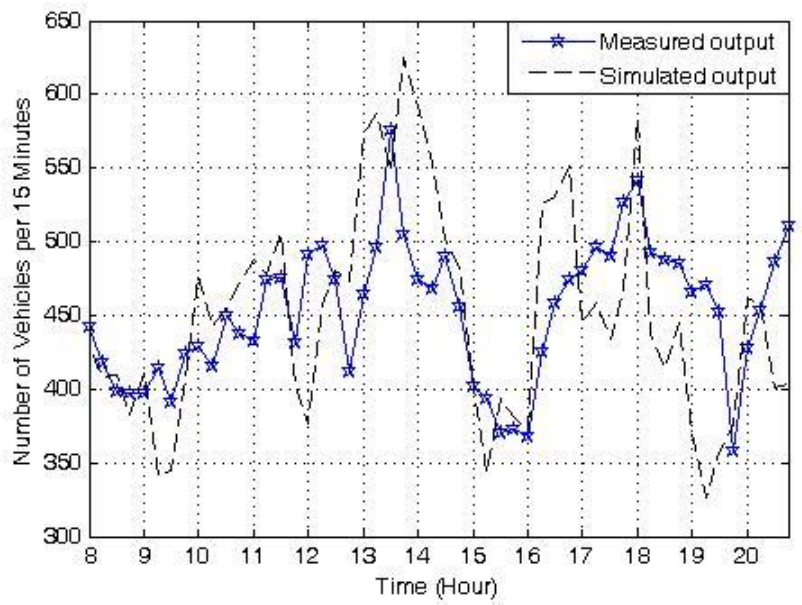

Figure 12. Average number of vehicles travelling over different days from 8:00 to 21:00 at Omar Ibn Al-Khattab Road 
Some steps and regulations, if taken, would help alleviate the traffic congestion problem faced at First Ring Road. Regulating the traffic flow from all roads to the area would help restricting the flow to a certain number per time period. This can be achieved by installing traffic lights in the area right before the ring road. If these lights are synchronized to allow certain number of vehicles, it will limit the number of vehicles on the ring road to a certain acceptable capacity. Information and communication technology can play a significant role in reducing the traffic congestion such as electronic boards, a local radio channel to broadcast traffic news and sending SMS messages to mobile phones within the city and GPS systems. The area represents almost the only link among different directions. Users of these roads are forced to go through the area if they want to cross from one direction to other direction. Although, it might be expensive, bridging over the area may solve most of the problem.

\section{CONCLUSION}

In this work, traffic movement on the ring road around Al-Masjid Al-Nawabi which experiences intense traffic especially during Hajj and Umrah seasons was chosen as a case study. Traffic movement data was collected from manual counting and machine measurements. To understand the traffic behavior, the data were analyzed and verified using statistical analysis. A computational model for the traffic distribution along the roads intersecting with First Ring Road was built using linear least squares method with constraints. The linear least square problem was formulated by minimizing the difference between the measured number of vehicles and the sum of numbers of vehicles from all entrances of Ring Road that move out at each road. A simulation program for the computational model was developed using Matlab. This program uses the number of vehicles at each entry of the ring road obtained from measurement data and produces the number of vehicles moving out of each exit of the ring road. The simulation results show good agreements with the measured number of vehicles at each road intersecting with Ring Road. Thus the model can be used as a prediction model of vehicle movements. Finally, the analysis and the model can substantially replicate the traffic behavior on First Ring Road.

\section{ACKNOWLEDGMENT}

The authors would like to thank and acknowledge "The Custodian of the Two Holy Mosques Institute of Hajj researches," at Umm Al-Qura University, Makkah, Saudi Arabia, for their financial support under research grant number: 43122004 during academic year 2010/2011.

\section{REFERENCES}

Alginahi, Y. M., Kabir, M. N., \& Mohamed, A. I. (2013). Optimization of High-CrowdDensity Facilities Based on Discrete Event Simulation. Malaysian Journal of Computer Science, 26(4), 312-329.

Baby, S., and Al-Sarawi, M. A. (2011). Traffic Environmental Assessment Studies for Township Re-development: Present Status and Future Prediction. International Conference on Biology, Environment and Chemistry, Vol. 1, IACSIT Press, Singapore.

Bing Maps (2013). Retrieved from http://www.bing.com/maps/ 
Central Department for Statistics and Information (2013) Retrieved from http://www.cdsi.gov.sa/2010-07-31-07-00-05.

Diliman, Q. C. (2005). Traffic impact assessment for sustainable traffic management and transportation planning in urban areas. In Proceedings of the Eastern Asia Society for Transportation Studies, Vol. 5, 2342-2351.

Google Map (2012). Retrieved from https://maps.google.com/.

Han, X., and Naeher, L. P. (2006). A review of traffic-related air pollution exposure assessment studies in the developing world. Environment international, 32(1), 106-120.

Jin, W. L. (2012). A link queue model of network traffic flow. arXiv preprint arXiv:1209.2361. Retrieved from, http://arxiv.org/pdf/1209.2361.pdf.

Li, R., and Lu, H. (2009). Combined neural network approach for short-term urban freeway traffic flow prediction. In Advances in Neural Networks-ISNN, 10171025.

Munir, A. and Pham, J., (2012). Proposed Melancthon Quarry Traffic Assessment Study. Morrison Hershfield Limited, Final Report, Retrieved from http://highlandcompanies.ca/images/uploads/pdf/application/17_Traffic_Assess ment_Study.pdf.

URS Canada Inc. (2009). Traffic Assessment - Technical Study Report, Durham York Residual Waste EA Study, Report No. 1009497. Retrieved from https://www.durhamyorkwaste.ca/Archive/pdfs/study/ea-study-docs/studydocjuly31/Appendix-C-10-Traffic-Assessment-Technical-Study-Report.pdf.

Xu, Y., Kong, Q. J., Lin, S., and Liu, Y. (2012). Urban traffic flow prediction based on road network model. 9th IEEE International Conference on Networking, Sensing and Control (ICNSC), 334-339.

Yu-fan, L., and Yan, W. (2011). Public traffic planning based on green traffic concept. 2011 International Conference on Intelligent Computation Technology and Automation (ICICTA), Vol. 2, 1146-1148. 